South Africa continues to put off signing nuclear treaty

\section{Oxford}

SouTH Africa again faces possible expulsion from the International Atomic Energy Agency (IAEA) at its annual general assembly in September. This follows its continued refusal to sign the Nuclear Non-proliferation Treaty (NPT), despite a statement by State President P.W. Botha on the eve of last year's general assembly that it was prepared to begin negotiations to that end. He added that South Africa would consider accepting safeguards on all its nuclear installations (a specific provision of the treaty), but that Pretoria's attitude would depend on the outcome of the assembly.

Botha's statement successfully stalled a Nigerian bid to expel South Africa, following a recommendation from the agency's board of governors last June that South Africa be suspended. This in turn followed the breaking off of IAEA negotiations with South Africa in December 1986 over safeguards at its new commercial enrichment plant, and 16 years of unsuccessful attempts to get it to sign the NPT. Interestingly, the United States secured the cooperation of the Soviet Union in thwarting South Africa's expulsion, on the grounds that the agency was able to exercise more control over its nuclear programme if it remained a member. A compromise solution was instead adopted, agreeing to renew attempts to expel South Africa in a year's time, giving it a period of grace in which to realize its stated intentions. Proposed by the Mexican delegation and seconded by Algeria, this resolution was adopted by 60 votes to 28 , the United States, the European Communities and other Western countries voting against it.

Botha raised Western hopes that South Africa would sign the treaty at last; Richard Kennedy, deputy head of the US delegation and a member of the agency's board of governors, criticized the failure of the resolution to take note of "the potential substantial development" posed by Botha's statement. This refers to the fact that South Africa had never before publicly countenanced acceding to the NPT. These hopes appear to have been illfounded, however, and if voting follows a similar pattern this year, the necessary two-thirds majority required to ensure South Africa's expulsion is likely to be narrowly achieved.

South Africa may well try to stave off expulsion yet again by offering to place under IAEA safeguards either its commercial enrichment plant or possibly both it and its pilot enrichment plant, while still refusing to sign the NPT. This would require little sacrifice on South Africa's part, as it would forfeit only the possibility of sabotaging the non-proliferation regime by exporting highly enriched uranium without IAEA safeguards in the future. As the commercial enrichment plant came on line recently but is unlikely to reach full capacity for some time, the possibility of South Africa becoming an exporter of highly enriched uranium, as it originally intended, seems very slim. Although South Africa will be capable of supplying the two reactors of the country's existing nuclear power station at Koeberg when current stocks of highly enriched uranium run out, it may even have difficulty supplying its planned second nuclear power station.

The pilot enrichment plant is widely regarded as the most likely source of South Africa's nuclear weapons, assuming

they exist. This plant was commissioned in 1975 , but became fully operational only in March 1977. Based on its capacity of 6,000 separative work units, it has been calculated that it is capable of producing up to two nuclear weapons each year. It could have produced one or two nuclear weapons by August 1977, when a testing site (subsequently dismantled) was detected by satellite in the Kalahari Desert. South Africa could subsequently have stockpiled about 20 nuclear weapons, and could thus place this plant under safeguards as well, while not undermining the possibility of its nuclear capability.

If South Africa does already possess nuclear weapons, it has little option but not to sign the NPT, and last year's statement was just yet another case of Botha successfully leading the West up the garden path. If it does not, then it will continue to delay signing as long as possible in order to keep the world guessing about its nuclear intentions.

Michael Cherry

\title{
Even conservatives share conservationist view of Soviet lake
}

\section{London}

Mr Egor Ligachev, the member of the Politburo of the Communist Party of the Soviet Union (CPSU) who is considered by western observers to be the custodian of hard-line conservative ideology, has sharply attacked the progress of conservation work at Lake Baikal. This lake, the largest and deepest body of fresh water in the world and the habitat of several unique species, including freshwater seals, came under increasing environmental threat during the Brezhnev era, in particular from the development of industries around the lake. Mr Gorbachev's glasnost campaign, however, brought to light the problems of the lake, and in April 1987 a special government and CPSU Central Committee resolution set out a programme for the protection of the lake and the "rational use" of it.

Although much has been done to implement this programme, Ligachev said, in particular, the closure of the yeastproducing facility at the Baikal pulp and paper combine, the rate of progress is too slow. Several ministries and government bodies are behind schedule in the installation of anti-pollution devices. The special Interdepartmental Monitoring Commission for the natural complex of Lake Baikal is failing to make full use of its statutory powers to deal with backsliding organizations, Ligachev says, and the funds and equipment allotted to pollution control have not always been used effectively. Researchers concerned with the problems of the lake, or working in enterprises situated close to its shores or tribu- taries, Ligachev says, must make greater efforts to develop and introduce wastefree technologies.

A particular black spot, environmentally speaking, is the north shore of the lake, in particular the new town of Severobaikalsk, which is being developed without proper study and in an "ill-thought-out manner". The very existence of this town has recently been questioned in the Soviet media. Ligachev appears to share these views asking "is it really necessary to create yet another industrial centre here, at Severobaikalsk".

Ligachev urges that to be effective the whole package of conservation measures for the lake must be carried out simultaneously and "unconditionally". Yet he did not mention one of the main threats to the well-being of the lake, the condition of the Selenge river. This river which provides about 60 per cent of Baikal's wate, rises in the Mongolian People's Republic, where indiscriminate treefelling has led to a considerable degrease in the Selenge's flow. During the past few months, the Mongolian government and Party have shown an increasing awareness of this problem and the need to embark on urgent re-forestation work, and at the beginning of July, the first ever SovietMongolian environmental round table was convened in the Mongolian capital, Ulan Bator, to discuss the protection of lakes Baikal and Huvsgul. But Ligachev makes no reference to this meeting, nor to the Mongolian aspect of the Baikal problem, but treated it as if it was a matter purely for the Soviets.

Vera Rich 